\title{
EFFECT OF WITH/WITHOUT AGITATIONOF AGRICULTURAL WASTE ON BIOGAS PRODUCTION FROM ANAEROBIC CO-DIGESTION-A SMALL SCALE
}

\author{
${ }^{1}$ Naphon Keanoi, ${ }^{1}$ KanokornHussaro and ${ }^{2}$ Sombat Teekasap \\ ${ }^{1}$ Rattanakosin College for Sustainable Energy and Enviroment, \\ Rajamangala University of Technology Rattanakosin, \\ Puthamonthon Sai 5, Salaya, Puthamonthon, NakhonPathom, 73170, Thailand \\ ${ }^{2}$ Department of Mechanical Engineering, Faculty of Engineering, \\ Eastern Asia University, Thanyaburi, PathumThani, 12110, Thailand
}

Received 2014-02-03; Revised 2014-02-05; Accepted 2014-03-04

\begin{abstract}
The growing worldwide concerns over environment, health and monetary aspects have triggered a search for efficient and economic renewable sources of energy production. Agricultural sector holds the potential for development of one of the major source of renewable energy such as biogas. In this study, CSTR-small scale fermentation (200 L stainless steel) was studied to observe the effect of stirring for natural water, cow dung, rice straw and water hyacinth ratio $(2: 1: 1: 1)$, which there are suitable of $\mathrm{C}: \mathrm{N}$ ratio at 31.1: lon the biogas and methane production at ambient temperature $\left(31^{\circ} \mathrm{C}\right), 6.7-7.2$ and $6.7-7.8$ of $\mathrm{pH}$ for with/without stirring digester, respectively, for 52 days. The result showed that the biogas production increased progressively with stirring digester. The maximum biogas production and methane concentration was $98.56 \mathrm{~L}$ /days and $64.07 \%$ was obtained at stirring digester. This gave an increase of 7.56 over without stirring digester. Thus, agitation of digester can be used effectively as an operating strategy to optimize biogas production.
\end{abstract}

Key words: Agitation, Biogas Production, Methane Content, Amount of Biogas and Anaerobic Co-Digestion

\section{INTRODUCTION}

Energy issues and global warming is a major problem in the world. Fosil fuel will be used up within 40 years and natural gas within 60 years that it is the data from the Electricity Generating Authority of Thailand.Thailand's oil consumption increased 3.9\% from the year 2010 to 2011, increased from 697,537 barrels per day is 724,539 barrels and natural gas production totaled 1,305,530 million cubic feet, or an average of 3,577 million cubic feet per day which is increased $2.1 \%$ from the previous year. Crude oil imports in the year 2011 totaled 39,637 million tons of oil equivalent and a total of 42,992 million tons of oil equivalent up $8.5 \%$ in 2012 . Imported oil in the year 2011 totaled 2,07 1 million tons of oil equivalent. Year 2012 totaled 2,663 million tons of oil equivalent, up $28.6 \%$. Imported natural gas in the country. Year 2010 totaled 9,744 million tons of oil equivalent Year 2011.

Totaled 9, 910 million tons of oil equivalent, up $1.7 \%$. Energy use of fossil fuelsupplies. Especially in the power generation, industrial and transportation. They are affect the climate of the country. The burning of fossil fuels. It is as ever negative impact on the environment. The current state of the earth's climate has changed dramatically. As the cause of the observed global warming of the earth's temperature is rising. The main cause of the greenhouse effect is pollution from main cause of the greenhouse effer

Rajamangala University of Technology Rattanakosin, Puthamonthon Sai 5, Salaya,

Puthamonthon, NakhonPathom, 73170, Thailand 
gas properties in absorbing heat energy reflected from the earth back into the atmosphere such as carbon dioxide, methane, chlorofluorocarbon, nitrous oxide, sulfur hexafluoride. These gases are used in industrial processes or the exhaust from burning fuels in the transportation industry or to produce electricity. Caused by burning fossil fuels such as coal, oil, natural gas or hydrocarbons. It is capable of trapping heat in the earth without releasing heat into the atmosphere so a manner similar to the principles of greenhouse crops known as the greenhouse effect. From the report of the Department of Land Development, Thailand can produce the quantity of stubble and rice straw each year 50 to 60 million tons. Burning stubble and rice straw will create carbon dioxide amount 27 million tons and spread on surface of the Earth. The ground stubble burning will lose nitrogen 0.0038-0.0056 $\mathrm{kg} \mathrm{m}^{-2}$, phosphorus $0.0005 \mathrm{~kg} \mathrm{~m}^{-2}$ and potassium $0.0098 \mathrm{~kg}$ $\mathrm{m}^{-2}$. As a result, the loss of nutrients in the soil and pollutioncause from the burning of rice straw and stubble is also a greenhouse gas, into the atmosphere of the world and also creates air pollution leading to global warming. Research Development and Hydrology of Department of water resources reported that water hyacinth is a weed poses a problem in the river are a lot is floating plants and can be spread by water currents. Marine and Coastal Resources Institute Prince of Songkla University reported that the seeds of water hyacinth can be stored for up to 30 years. Distribution fast and will increase steadily until very tightly in a short time, causing problems for the water crisis in terms of the environment, including economic, social and recreation impact in many sectors including irrigation, fisheries and maritime sectors, especially people who have to live by the water. Year 2011, Department of Livestock Development in Thailand reported that the amount of cow 6.58 million cow and cow dung amount $11,700 \times 10 \mathrm{~kg}^{-6}$.

Researchers are particularly interested in renewable energy from biogas into energy that causes less global warming and raw materials used in production make it easy to find gas. For this reason, researchers are interested in the production of biogas from cow dung digestion of biomass materials and biomass material used is rice straw and water hyacinth. Study of research articles on biogas production from different materials such as biogas from sewage to have methane $55-65,35-45 \%$ carbon dioxide, $<1 \%$ nitrogen; digester biogas from organic waste to have methane gas $60-70,30-40 \%$ carbon dioxide, $<1 \%$ nitrogen and the landfill system to have methane $45-55,30-40 \%$ carbon dioxide, 5-15\%, nitrogen. The gas also contains hydrogen sulfide and other sulfur compounds and aromatic compounds such as siloxanes and Halogens (Matjaz et al., 2010).

Traditionally, co-digestion of animal manure with agricutural residues is gaining momenum in many part of the world. Agricultural residues such as straws and corn stalks are produced in large quantities in both US and other countries every year, which, due to its organic nature, can be a valuable alternative feedstock for biogas production (Xiao et al., 2010). Water hyacinth is lignocellulosic biomass consisting of a complex mixture of lignin, hemicelluloses and cellulose. Both the cellulose and hemicelluloses are polymers of sugars and are thereby a potential source of sugars. As a result, the coversion of water hyacinth to fuels has received significant in the last few decades. However, the cellulose content of water hyacinth was much lower when compared with wood and straw (Jing et al., 2013). Biogas yield is affected by temperature, $\mathrm{pH}$, Carbon to Nitrogen ratio $(\mathrm{C}: \mathrm{N}$ ratio) and loading rate. A $\mathrm{C}: \mathrm{N}$ ratio ranging from 20 to 30 is considered optimum for anaerobic digestion (Keanoi et al., 2013). Co-digestion of animal manure with agricutural residues are solve for adjust the suitable $\mathrm{C}$ : $\mathrm{N}$ ratio. Anaerobic digestion of animal slurry for biogas production is commonly practiced in Continuously Stirred Tank Reactor (CSTR) and occasiionally in plug-flow reactor. To improve the economics of biogas systems, the amount of energy produced per unit manure treated and the value of digested material as fertilizer sholud be maximized while the investment and operation costs should be minimized (Prasad et al., 2009). One reson for the loss of degragable organic matters is due to "short-circuit" of a portion in the feed which retained in the reactor for shorter time than the nominal retention time. A conventional single CSTR is simple to operate but less efficient in terms of effluent quqlity compared to a twophase system where acidogenes is step with short HRT is followed by methanogenes is step with long HRT. However, although the two-phase system has widely been suggsted for enhancing digestion performance, on the other hand, it is also sensitive to the substrate with high easily degradable organic load and in that case a single CSTR can achieve nearly the same yield as the two-phase system (Kanokwan and Angelidaki, 2009).

Lopburi province: Located in the central region of Thailand, on the left bank of the Lopburi River. It 
away from Bangkok to the north along phaholyothin road distance $153 \mathrm{~km}$. It has an area of approximately $6,641.859 \mathrm{~km}^{-2}$. Most people are farmers and there is cattle.The rice growing area $1605 \mathrm{~km}^{2}$, sugarcane growing area of approximately $807 \mathrm{~km}^{2}$ and corn planted area of approximately $756 \mathrm{~km}^{2}$. Farm animal economy of the province, such as chicken and cow farms. In 2006, 2007 and 2008 evaluation found the energy potential from animal dung in Lopburi province was $12.89,14.05$ and $19.60 \mathrm{k}$ toe, respectively. There are three main reasons for researchers to become interested in biogas production from co-digestion of cow dung with biomass in Lopburi province; reduce global warming; Lopburi is a lot of rice straw. The people burn the rice straw in rice fields and cow food part. Rice straw burning can increase carbon dioxide, global warming and create pollution in the village; reduce water hyacinth in the river; increase the flow of water in the river quickly. Because water hyacinth is a barrier to the flow of water in the river.Water is a factor for growing rice.

The aim of this research was to assess the viability and feasibility of co-digesting three agricultural residues (cow dung, rice straw and water hyacinths) with/without agitation in term biogas production on a small-scale. The amounts of crop wastes (rice straw and water hyacinths) added to cow dung were calculated to adjust the $\mathrm{C}$ : $\mathrm{N}$ ratios of the digester content to 31.1 based on previously findings (Keanoi et al., 2013) which was optimized on biogas product. The impact of the used crop wastes on biogas production in the small-scale digester, methane content and amount of biogas was also discussed and the effect of stirr on biogas product was presented.

\section{MATERIALS AND METHODS}

\subsection{Materials}

The typical raw materials for agricultural biogas plants include natural water, cow dung, rice straw and water hyacinth, which were collected from Lopburi Provice, Thailand. Water hyacinth was dried in the sun for 1 week and grinded to pass through $5 \mathrm{~mm}$ sieve pieces. The collected rice straw was a grinded to about 5 $\mathrm{mm}$ sieve pieces. Then the raw materials were kept in a tightly closed plastic container and stored at ambient temperature of $25-30^{\circ} \mathrm{C}$. The cow dung was sun dried for a period of 2 weeks to preserve its microbial population and then crushed mechanically using a mortar and pestle. Natural water was collected from canal in Ampor
Banmie, Lopburi Provice, Thailand. Raw materials were taken for compositional analysis before the anaerobic digestion tests on $2: 1: 1: 1$ of natural water to cow dung: Rice straw: Water hyacinth, which this ratio was optimized on biogas product (Keanoi et al., 2013).

\subsection{Experimental Method}

Digestion of raw materials was carried out two system of digestion (with and without stir on digester) at phychrophilic temperature for 52 days.

The experimental were conducted in special designed steel fermenter apparatus that contained two $200 \mathrm{~L}$ capacity digester (with/without stirring) and two water displacement gas collection reservoir. Schematic experimental biogas fermentation set up is presented, as shown in Fig. 1. Set of two reactors were used as digesters which the first digester had stirrer and the second digester without stirrer. The experiment was performed with anaerobic co-digestion with the ratio of natural water to raw materials were $2: 1$ at ratio raw martials of cow dung to rice straw to water hyacinth were $1: 1: 1$, which is the optimize resulted of biogas product from laboratory scale.

\subsection{Characterization}

Total Solid (TS), Volatile Solids (VS) and pH were measured according to the standard methods for water examination. TS test and VS testhave been done by constant weight drying method. $\mathrm{pH}$ test was determined by using $\mathrm{pH}$ meter. Biogas composition was determined by using a gas chromatography equipped with a Thermal Conductivity Detector (TCD). Helium was used as a carrier gas with a flow rate of $40 \mathrm{~mL} \mathrm{~min}{ }^{-1}$. The temperature of detector was $120^{\circ} \mathrm{C}$. The injection from gasbag was $1 \mathrm{~mL}$ (Keanoi et al., 2013). The amounts of biogas product were measured by height of the storage tank biogas (as shown in Fig. 2) and calculate by Equation 1 and 2.

$$
\begin{aligned}
& \mathrm{v}=\frac{\pi \mathrm{d}^{2}}{4} \cdot 1 \\
& \mathrm{l}=\mathrm{X}-\mathrm{h}
\end{aligned}
$$

Where:

$\mathrm{V}=$ Amount of biogas $\left(\mathrm{cm}^{3}\right)$

$\mathrm{D}=$ Diameter of storage tank biogas. $(\mathrm{cm})$

$\mathrm{L}=$ High of storage tank biogas. $(\mathrm{cm})$

$\mathrm{X}=$ The recent high $(\mathrm{cm})$

$\mathrm{H}=$ Height last $(\mathrm{cm})$ 
Naphon Keanoi et al. / American Journal of Environmental Science 10 (1): 74-85, 2014

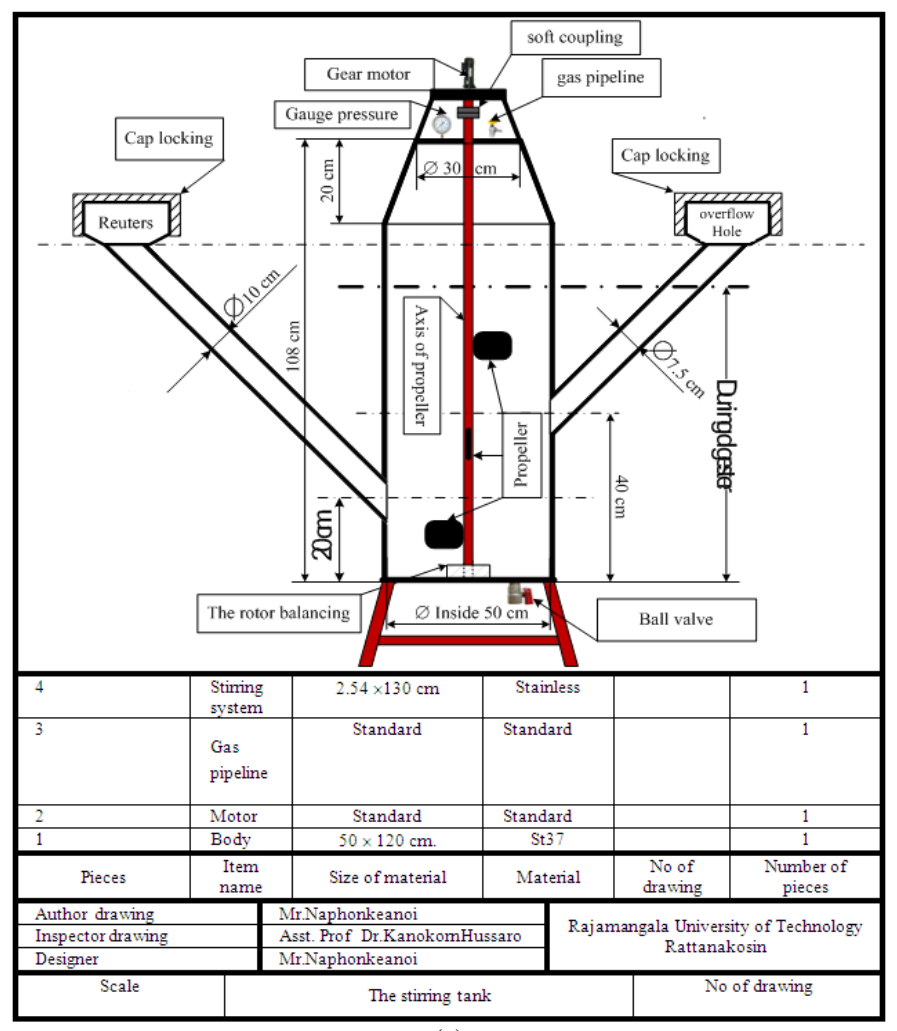

(a)

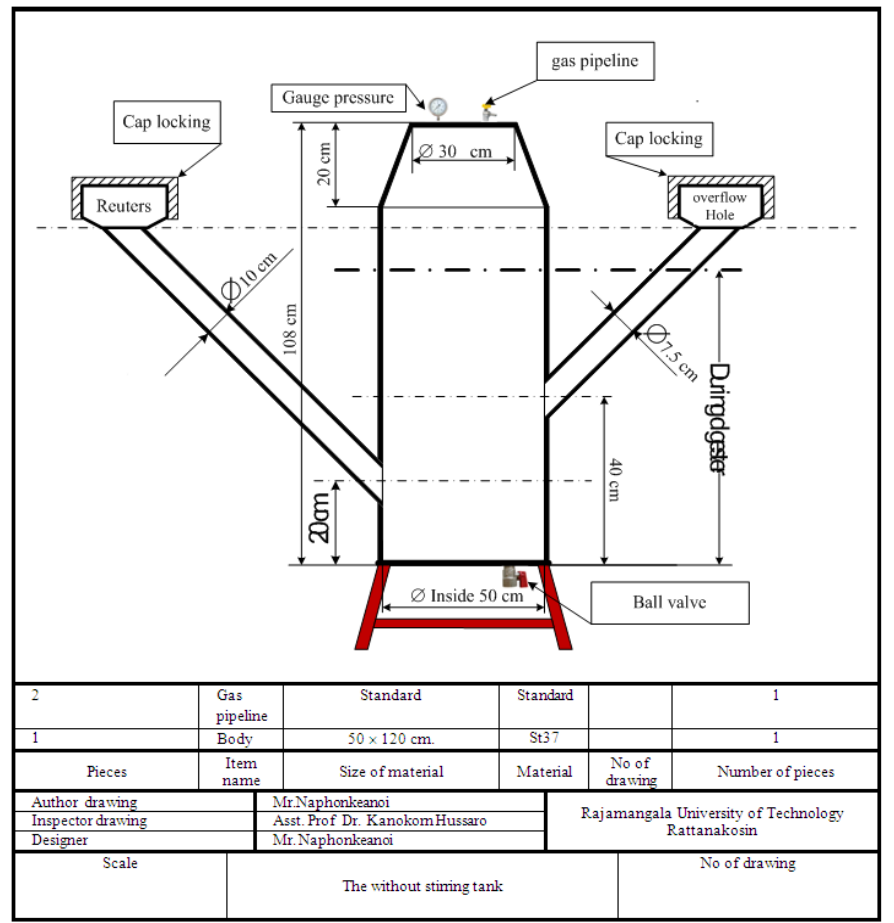

(b) 
Naphon Keanoi et al. / American Journal of Environmental Science 10 (1): 74-85, 2014

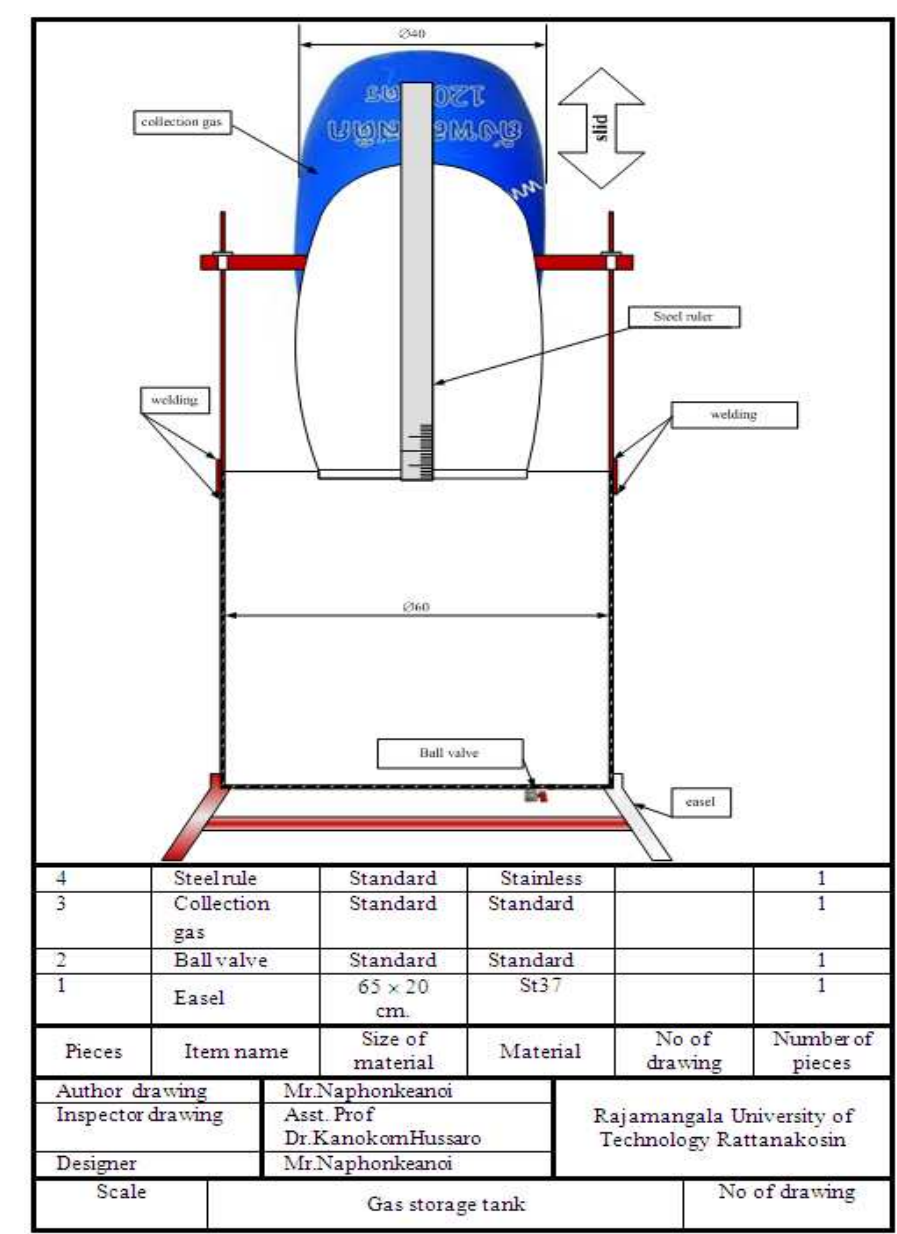

(c)

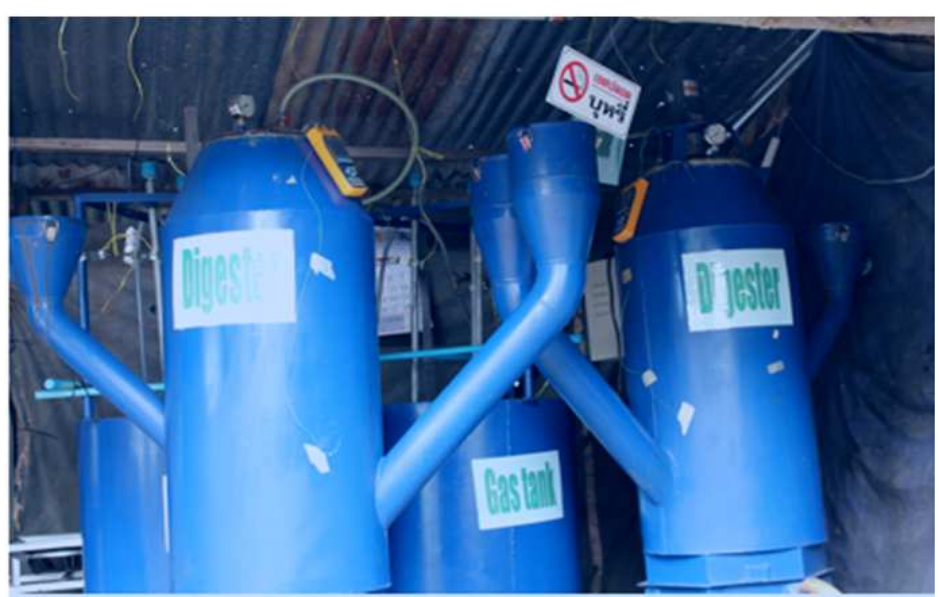

(d)

Fig. 1. (a) Schematic of biogas production for digester with stirring. (b) Schematic of biogas production for digester without stirring. (c) Schematic of biogas production for water displacement gas collection reservoir. (d) Schematic of twosmall-scale digester (with/without stirring) for biogas production 

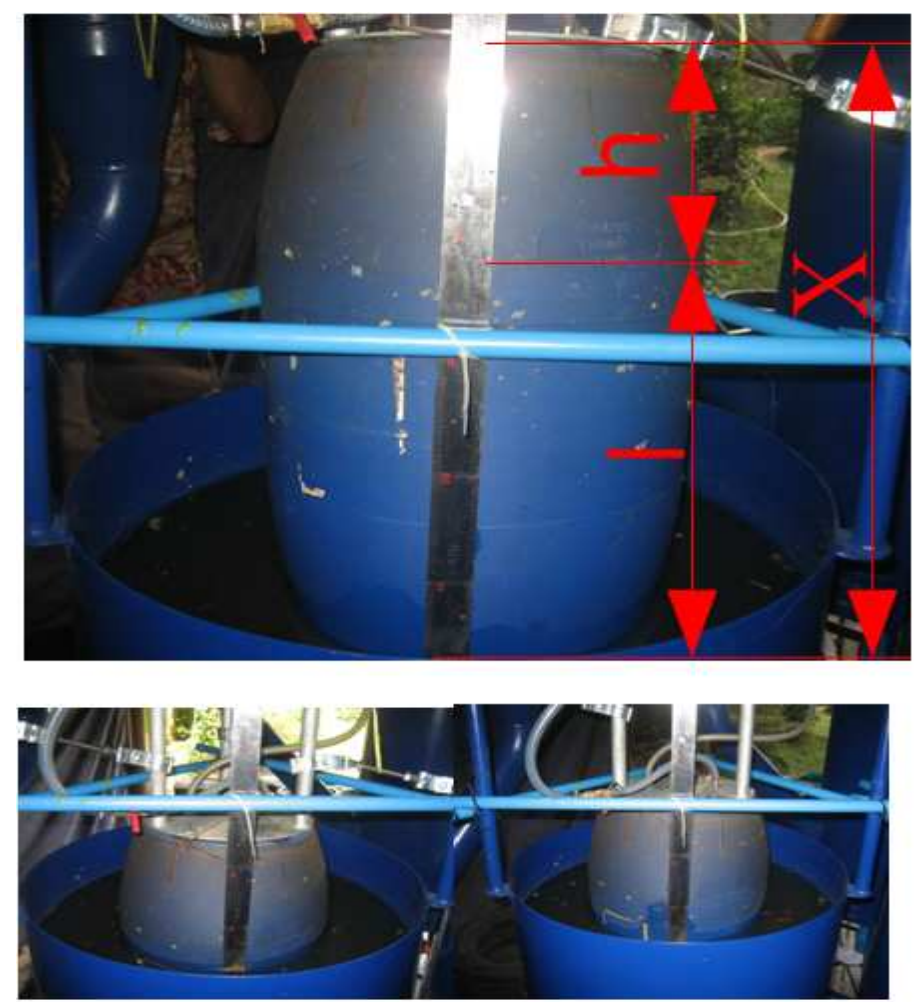

Fig. 2. Measuring the amount of biogas product

\section{RESULTS}

\subsection{Characteristics of Raw Material}

Component characteristics of raw materials fed to reactor are summarized in (Keanoi et al., 2013). The cow dung used in the experiments contained relatively high solid content. Therefore dilution is required to fit anaerobic reactors condition of 8 and 12\% (Nasir et al., 2012). Meanwhile, initial concentration of COD and $\mathrm{NH}_{3}$-Nof cow dung were at higher value.

Carbons to nitrogen ratio of the substrates feeding to reactor are 31.2, produced total quantity of biogas which similar to the previously report by Mohd et al. (2008).

\subsection{Effect of Agitation on Biogas Production}

In particular, effect on temperature it was found that the temperature of the digester without stirred tank was maximum at $32.08^{\circ} \mathrm{C}$, there was amount biogas 91.08 liter and the temperature of the digester stirred tank was maximum at $31.98^{\circ} \mathrm{C}$, there was amount biogas 98.56 liter, respectively (Fig. 3).
The experiment was also monitored with respect to changes in Total Solids (TS) and volatile solids content in biogas slurry. An overview of results based on TS and VS variation during a 52-day settling period is shown in Fig. 4, which gives the reduction in TS and VS for different designed. Biologically activedigested manure, material used in with stirring digester and without stirring digester, had similar chemical characteristics with respect to TS and VS after digestion. TS and VS content of with/without stirring digester were in the range of $8-19.3 \mathrm{mg} \mathrm{L}^{-1}$, 4.7-26.4 $\mathrm{mg} \mathrm{L}^{-1}, 3.3-7.9 \mathrm{mg} \mathrm{L}^{-1}$ and 2.2-9.8, respectively. It can be seen that maximum decrease of $8 \mathrm{mg} \mathrm{L}^{-1}$ and $4.7 \mathrm{mg} \mathrm{L}^{-1}$ in TS and $3.3 \mathrm{mg} \mathrm{L}^{-1}, 2.2 \mathrm{mg}$ $\mathrm{L}^{-1}$ in VS were observed for the digester with stirring and digester without stirring at 34 day, respectively, for which the maximum biogas volume was obtained. These results indicated stirring of digester had affected the solids content and apparently resulted in loss of $\mathrm{NH}_{4}{ }^{+}-\mathrm{N}$.

The results of effect of stirr of digester on $\mathrm{pH}$ for biogas production in this study is shown in Fig. 5. The 
$\mathrm{pH}$ values before digester of with and without stirred tank in the range 7.2-8.4 and 7.3-8.4, respectively. On the contrary, the $\mathrm{pH}$ values on after digester of without and with stirred tank, have difference, which were 6.77.8 and 6.7-7.2, respectively. $\mathrm{pH} 7$ gave the best biogas volume. This is in agreement with the reports of oher authors (Okeh et al., 2014). $\mathrm{pH}$ is an important factor for keeping funtional anaerobic digestion. The accumulation of intermediate acids leads to $\mathrm{pH}$ drop during fermentation. It can be seen that biogas production was maximum in case of with stir digestion, which this was due to lower average $\mathrm{pH}$ value and close to 7 . The maximun amount of biogas produced was 98.561 in case with stir digestion as compared to 91.081 for without stir digestion. These results indicated stirring of digester had affected to $\mathrm{pH}$ value on biogas production.

\subsection{Methane Concentrations and Biogas Volume of Biogas Production}

An initial co-digestion study of natural water, cow dung, rice straw and water hyacinth at the ratio of $2: 1: 1: 1$ with 31.2 of $\mathrm{C}: \mathrm{N}$ ratio, produced high total quantity of biogas (Keanoi et al., 2013) forwith/without agitation were conducted in $200 \mathrm{~L}$ reactor, to see the best composition ratio on the amount of biogas and methane production. The C:N ratio of feedstock is an important parameter for biogas production. Nitrogen present in the feedstock has two benefits: (i) it provides an essential element for synthesis of amino acids, proteins and nucleic acids and (ii) it is converted to ammonia which, as a strong base, neutralizes the volatile acids produced by fermentative bacteria and helps maintain neutral $\mathrm{pH}$ conditions essential for cell growth (Hifjur and Mondal, 2012). The effects of stir digestion on methane concentration and biogas volume are shown in Fig. 6 and Table 1, it can be seen that for digester with agitation, production of biogas is maximum and is 98.56 1 higher than digester without agitation (91.08 1), as compared to $7.56 \%$ higher for digester without agitation. Maximum methane content of with and without stir digester for biogas produced was found to be 64.07 and $62.12 \%$, respectively, it was found that the gas produced from digester with agitation was found that to be significantly different from digester without agitation.

From all results, it has been found that the biogas quality parameter in all digester is shown in Table 2 .

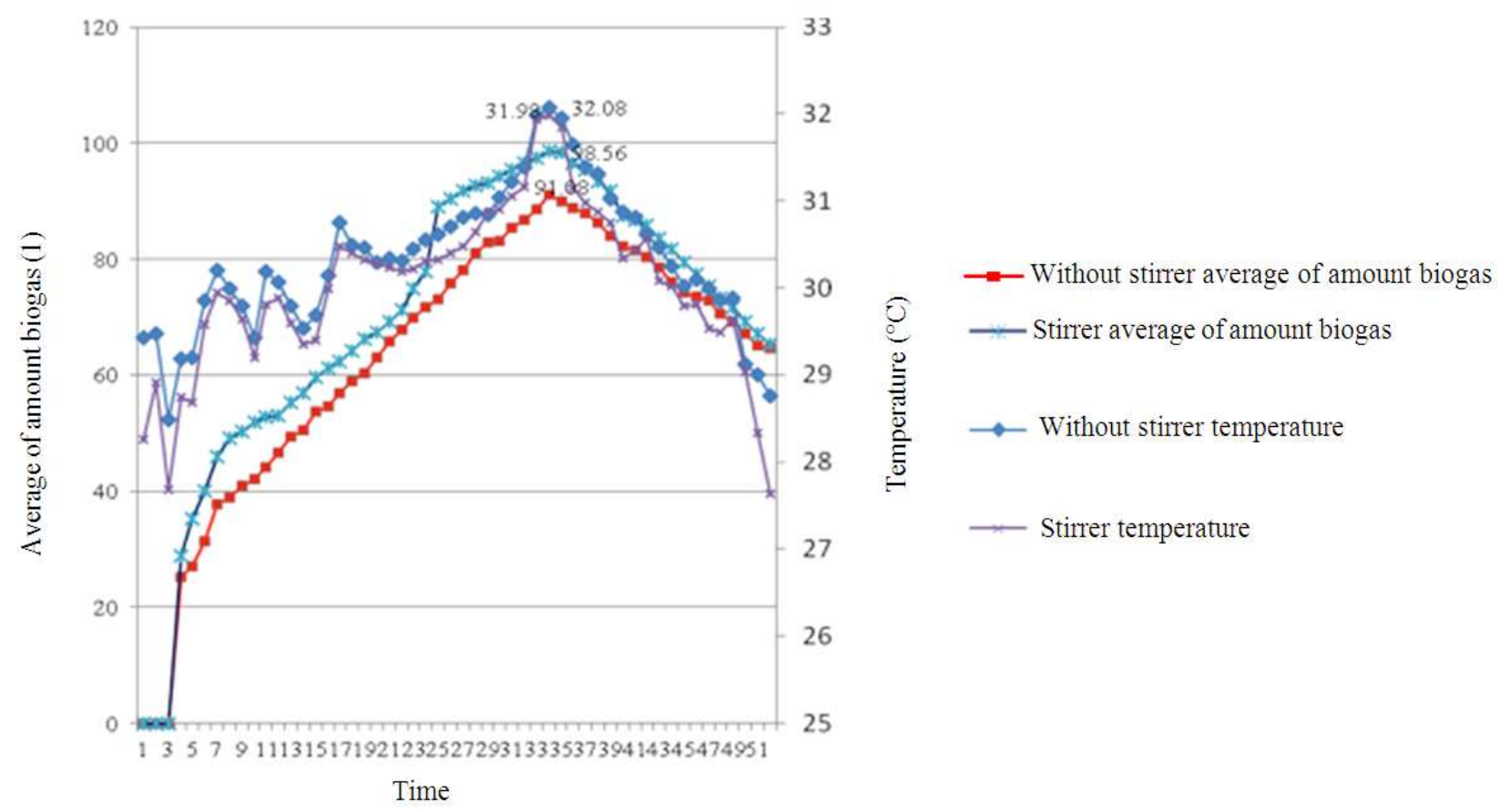

Fig. 3. Comparison of average temperature and average of amount biogas versus with/without stirred digester for 52 day 
Naphon Keanoi et al. / American Journal of Environmental Science 10 (1): 74-85, 2014

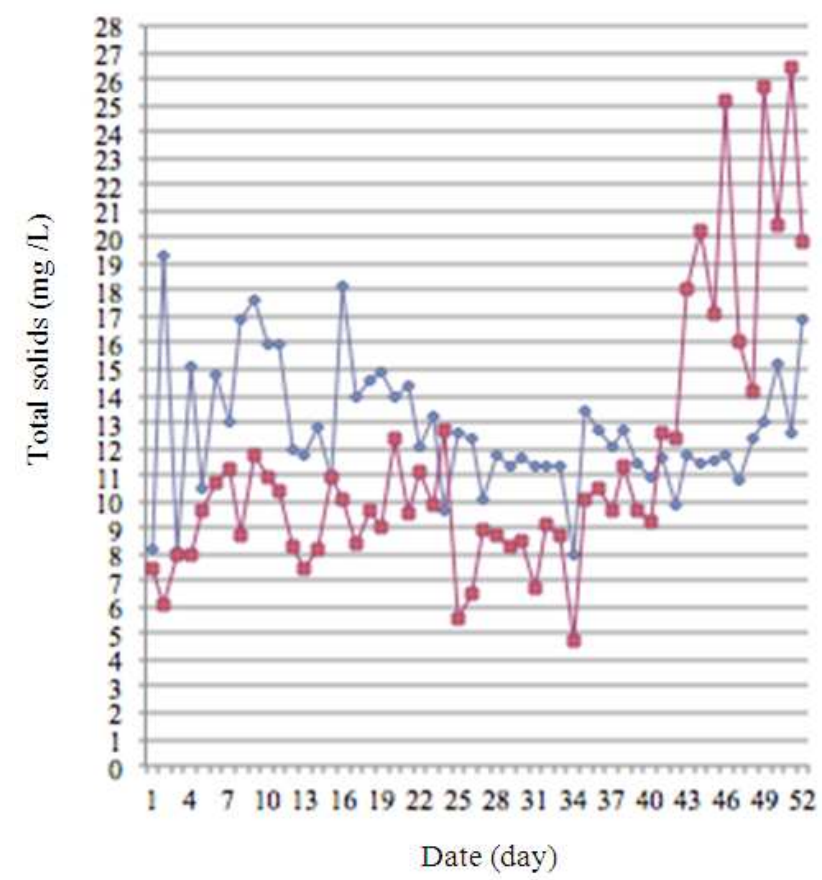

$\rightarrow\{\mathrm{TS}(\mathrm{mg} / \mathrm{L})\}$ stirred tank

$\rightarrow-\{\mathrm{TS}(\mathrm{mg} / \mathrm{L})\}$ without stirred tank

(a)

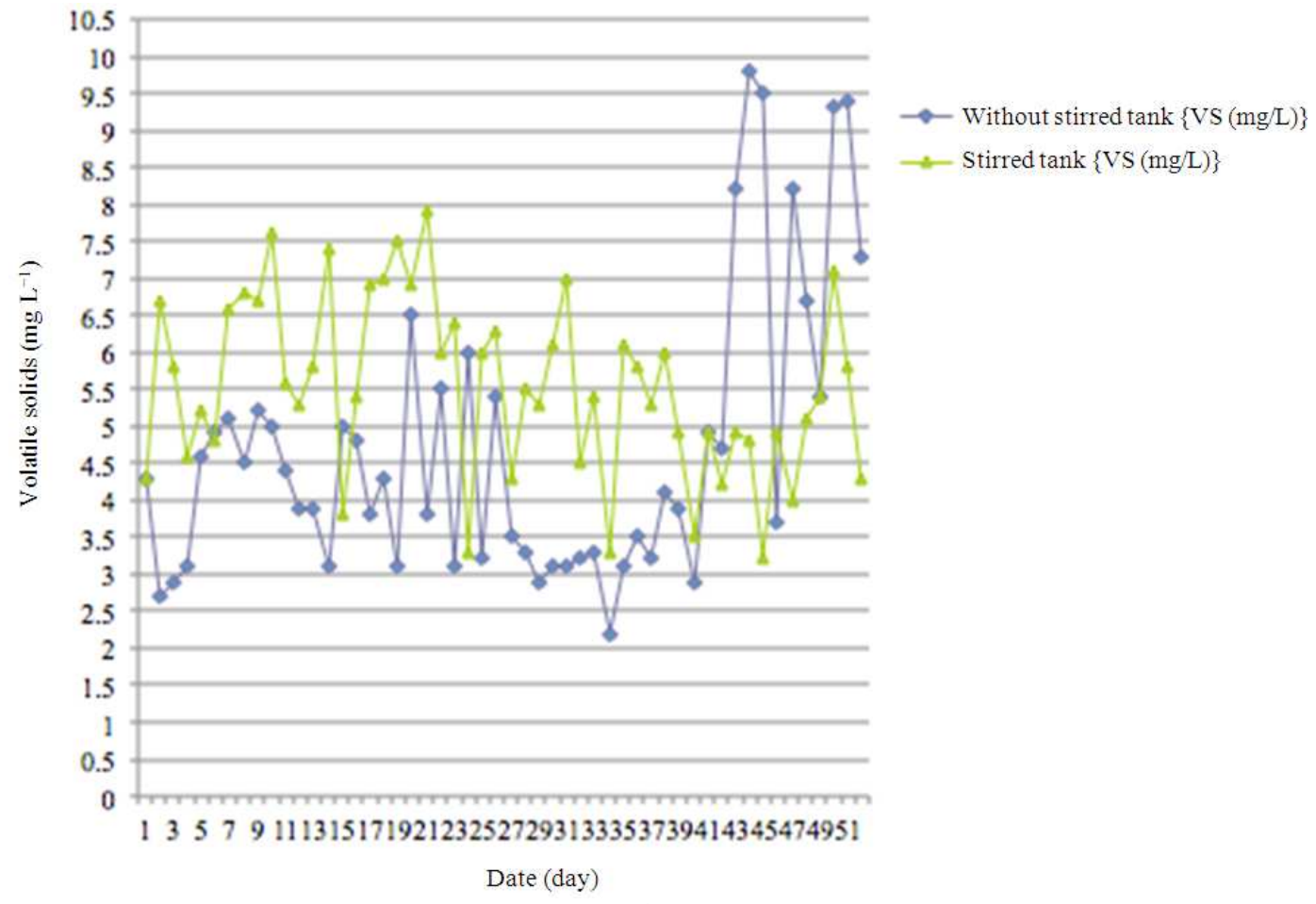

(b)

Fig. 4. Changes in (a) Total Solids (TS) and (b) Volatile Solids (VS) content of with and without stir digester for after digestion at 52 day 
Naphon Keanoi et al. / American Journal of Environmental Science 10 (1): 74-85, 2014

Table 1. Biogas production of with/without stirred tank (digester)

\begin{tabular}{|c|c|c|c|c|}
\hline \multirow[b]{2}{*}{ Day } & \multicolumn{2}{|l|}{$\mathrm{CH}_{4}$} & \multicolumn{2}{|c|}{ Average of amount biogas (L) } \\
\hline & (Stirred tank) & (Without stirred tank) & (Without stirred tank) & (Stirred tank) \\
\hline 1 & 0.3 & 2.64 & 0.00 & 0.00 \\
\hline 2 & 24.41 & 2.64 & 0.00 & 0.00 \\
\hline 3 & 28.96 & 11.81 & 0.00 & 0.00 \\
\hline 4 & 28.96 & 16.92 & 25.17 & 28.91 \\
\hline 5 & 30.36 & 35.61 & 27.13 & 35.18 \\
\hline 6 & 33.59 & 40.85 & 31.43 & 39.97 \\
\hline 7 & 34.95 & 43.29 & 37.80 & 45.88 \\
\hline 8 & 41.48 & 47.97 & 38.97 & 49.03 \\
\hline 9 & 48.20 & 54.19 & 40.94 & 50.29 \\
\hline 10 & 55.48 & 55.40 & 41.99 & 51.93 \\
\hline 11 & 55.13 & 54.92 & 44.03 & 52.79 \\
\hline 12 & 57.65 & 57.78 & 46.55 & 53.07 \\
\hline 13 & 57.16 & 57.45 & 49.37 & 55.33 \\
\hline 14 & 57.11 & 57.16 & 50.41 & 56.83 \\
\hline 15 & 56.85 & 56.42 & 53.77 & 59.71 \\
\hline 16 & 56.84 & 56.53 & 54.69 & 61.15 \\
\hline 17 & 56.04 & 56.09 & 56.81 & 62.36 \\
\hline 18 & 51.01 & 46.60 & 58.86 & 64.15 \\
\hline 19 & 48.35 & 50.64 & 60.36 & 66.25 \\
\hline 20 & 51.94 & 55.28 & 63.03 & 67.33 \\
\hline 21 & 54.66 & 54.67 & 65.69 & 69.14 \\
\hline 22 & 49.82 & 49.77 & 67.87 & 71.25 \\
\hline 23 & 47.41 & 45.79 & 69.92 & 74.95 \\
\hline 24 & 52.81 & 51.11 & 71.68 & 77.93 \\
\hline 25 & 55.98 & 53.99 & 73.05 & 88.96 \\
\hline 26 & 47.39 & 46.53 & 75.75 & 90.51 \\
\hline 27 & 51.47 & 53.24 & 78.18 & 91.76 \\
\hline 28 & 47.79 & 49.14 & 80.97 & 92.68 \\
\hline 29 & 52.54 & 47.46 & 82.97 & 93.15 \\
\hline 30 & 56.45 & 57.30 & 83.02 & 94.35 \\
\hline 31 & 59.11 & 58.47 & 85.34 & 95.45 \\
\hline 32 & 60.05 & 59.28 & 86.66 & 96.56 \\
\hline 33 & 62.27 & 61.57 & 88.57 & 97.46 \\
\hline 34 & 64.07 & 62.12 & 91.08 & 98.56 \\
\hline 35 & 59.54 & 62.27 & 90.04 & 98.46 \\
\hline 36 & 62.47 & 59.69 & 88.78 & 96.58 \\
\hline 37 & 60.68 & 60.19 & 87.78 & 95.48 \\
\hline 38 & 60.90 & 60.79 & 86.23 & 93.36 \\
\hline 39 & 60.69 & 59.80 & 84.02 & 91.76 \\
\hline 40 & 63.51 & 61.00 & 82.30 & 87.48 \\
\hline 41 & 61.54 & 61.47 & 81.56 & 86.72 \\
\hline 42 & 59.33 & 59.70 & 80.26 & 85.78 \\
\hline 43 & 60.00 & 58.96 & 78.45 & 83.49 \\
\hline 44 & 58.31 & 57.85 & 76.06 & 81.72 \\
\hline 45 & 57.55 & 58.17 & 74.24 & 79.42 \\
\hline 46 & 58.41 & 59.13 & 73.53 & 77.42 \\
\hline 47 & 58.89 & 58.87 & 72.90 & 75.41 \\
\hline 48 & 58.98 & 59.08 & 70.55 & 73.29 \\
\hline 49 & 59.34 & 59.30 & 69.14 & 71.77 \\
\hline 50 & 59.05 & 58.72 & 67.24 & 69.14 \\
\hline 51 & 58.89 & 56.19 & 65.07 & 67.24 \\
\hline 52 & 58.58 & 55.20 & 64.63 & 65.42 \\
\hline
\end{tabular}


Table 2. Biogas quality parameter

\begin{tabular}{|c|c|c|c|}
\hline \multirow{2}{*}{$\begin{array}{l}\text { Biogas quality } \\
\text { parameter }\end{array}$} & \multicolumn{2}{|c|}{ Reporting digester } & \multirow[b]{2}{*}{ Analytical method } \\
\hline & With stirr & Without stirr & \\
\hline Temp. digester $\left({ }^{\circ} \mathrm{C}\right)$ & 31.98 & 32.08 & Thermometer \\
\hline $\mathrm{C} / \mathrm{N}$ ratio & 31.20 & & CHNS/O analyzer $(\mathrm{Pe} 2400$ series $\Pi)$ \\
\hline$\% \mathrm{CH}_{4}$ (maximize) & 64.07 & 62.12 & $\begin{array}{l}\text { Gas chromatography equipped with a } \\
\text { Thermal Conductivity Detector (TCD) }\end{array}$ \\
\hline Maximize biogas product (L/day) & 98.56 & 91.08 & Water displacement \\
\hline
\end{tabular}

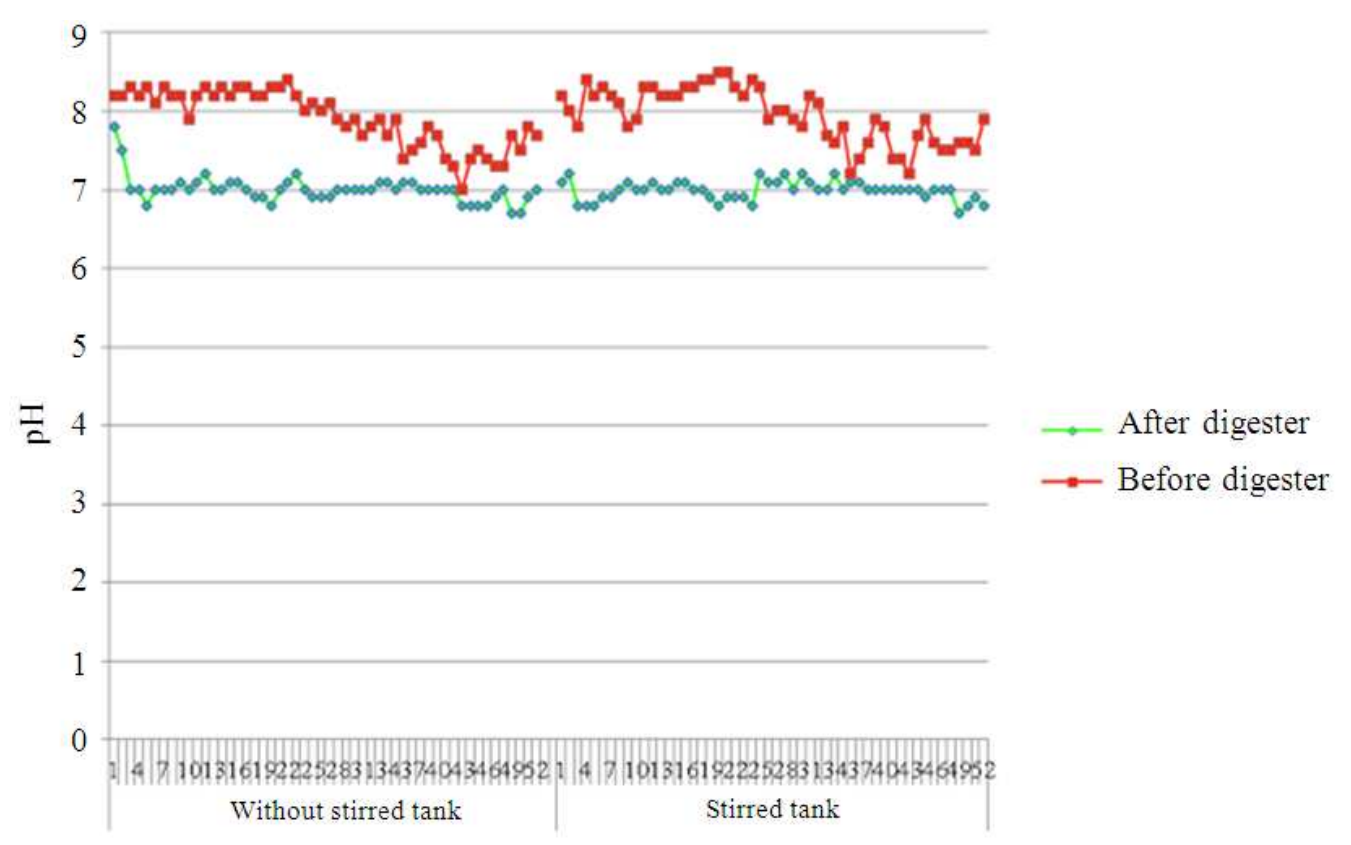

\section{Digester tank and time}

Fig. 5. $\mathrm{pH}$ value after/before of digester with/without agitation for biogas production 52 day at ambient temperature

\section{DISCUSSION}

The term "agitation" subsumes different ways of homogenizing the substrate or mixing it with water and co-substrate: Mixing and homogenizing the substrate in the mixing chamber, agitation inside the digester and poking through the in- and outlet pipes (small scale plants). The most important objectives of agitation are; removal of metabolites produced by methanogens (gas), mixing of fresh substrate and bacterial population (inoculation), preclusion of scum formation and sedimentation, avoidance of pronounced temperature gradients within the digester, provision of uniform bacterial population density and prevention of the formation of dead spaces that would reduce the effective digester volume.

Experimental results indicate that the suitable raw material ratio of natural water, cow dung, rice straw and water hyacinth for biogas production is $2: 1: 1: 1$. For maximum biogas and methane production and appropriate Carbon to Nitrogen $(\mathrm{C}: \mathrm{N})$ ratio must be followed (Keanoi et al., 2013). The higher methane content and amount of biogas along with digester with stirred than digester without stirred suggests that low $\mathrm{TS}$, VS and $\mathrm{pH}$, but mainly due to high biogas activity (flotation and gas production) aided agitation process. Therefore, the samples of the biogas production at with/without agitation, showing that methane content and amount of biogas had maximum with operated on agitation, compared to the corresponding digestion of the biogas product as shown in Fig. 6. The present results in practice suggest that biogas production can be optimized if a stirring period can be used effectively as a means of cell and solid material retention within the reactor. 


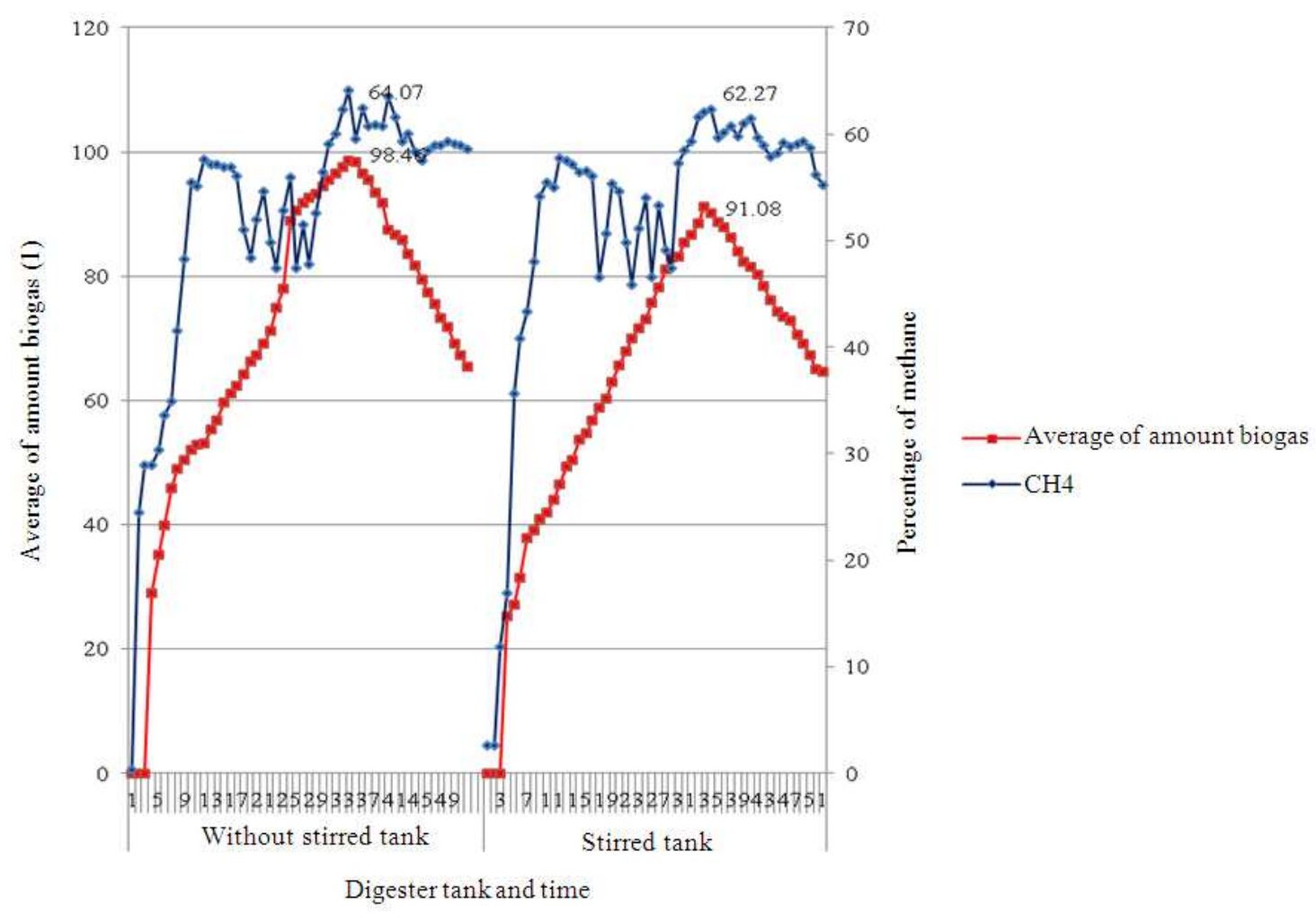

Fig. 6. Methane content and amount of biogas from digester with/without agitation for biogas production 52 day at ambient temperature

\section{CONCLUSION}

From the present study, it can be seen concluded that biogas production from natural water with cow dung and agricultural waste at ambient temperature for 52 days. The results support that cow dung is possible feedstock for anaerobic digestion on batch reactor $200 \mathrm{~L}$ capacity, in the ratio of 2:1:1:1 (C:N ratio at 31.1:1) at with/without stirred digester, the present of stirred influence its ability to do so. High methane content and amount of biogas along with digester with agitation is $64.07 \%$ and $98.56 \mathrm{~L}$, respectively, which is high microbial abundance, would be achieved if biologically active digested manure was allowed to settle on stirred than without stirred. Thus, stirring of digester can be used effectively as an operating strategy to optimize biogas production by stirring of digester by increasing amount of biogas about $7.56 \%$.

\section{ACKNOWLEDGMENT}

The gratefully acknowledge the provision of Scientific and Technological Research Equipment,
Chulalongkorn University researchers gratefully acknowledge the provision of Scientific and Technological Research Equipment, Chulalongkorn University and King's Mongkut University of Technology Thonburi.

\section{REFERENCES}

Hifjur, R. and S. Mondal, 2012. Biogas production potential of Jatropha seed cake. Biomass Bioenergy, 37 25-30. DOI: 10.1016/j.biombioe.2011.12.042

Jing, G., L. Chen, Z. Yan and L. Wang, 2013. Effect of ionic liqid pretreatment effect of ionic liquid pretreatment on the composition, structure and biogas production of water hyacinth (Eichhornia crassipes). Bioresource Technol., 132: 361-364. DOI: 10.1016/j.biortech.2012.10.136

Kanokwan, B. and I. Angelidaki, 2009. Serial CSTR digester configuration for improving biogas production from manure. Water Res., 43: 166-172. DOI: 10.1016/j.watres.2008.09.041 
Keanoi, N., K. Hussaro and S. Teekasap, 2013. The Effect of natural water with cow dung and agriculural waste ratio on biogas production from anerobic co-digestion. Am. J. Environ. Sci., 9: 518525. DOI: 10.3844/ajessp.2013.518.525

Matjaz, O., B. Mursec and P. Vindis, 2010. Biogas production from maize hybrids. J. Biomass Bioenergy, 34: 1538-1545. DOI: 10.1016/j.biombioe.2010.04.016

Mohd, S., S. Hisham and M. Wan, 2008. Effect of nitrogen source and carbon to nitrogen ratio on hydrogen production using C. acetobutylicum. Am. J. Biochem. Biotechnol., 4: 393-401. DOI: 10.3844/ajbbsp.2008.393.401

Nasir, I.M., I. Mond, R. Omar and A. Idris, 2012. Palm oil mill effluent as an additive with cattle manure in biogas production. Procedia Eng., 50: 904-912. DOI: $10.1016 /$ j.proeng.2012.10.098
Okeh, C., O. Chukwudi and C. Frederick, 2014. Biogas production from rice husks generated from various rice mills in Ebonyi State, Nigeria. Renewable Energy, 62: 204-208. DOI: 10.1016/j.renene.2013.07.006

Prasad, K., L. Ellegaard and I. Angelidaki, 2009. Optimisation of biogas production from manure through serial digestion: Lab-scale and pilot scale studies. Bioresource Technol., 100: 701-709. DOI: 10.1016/j.biortech.2008.07.023

Xiao, W., W. Yao, J. Zhu and C. Miller, 2010. Biogas and $\mathrm{CH} 4$ productivity by co-digesting swine manure with three crop residues as an external carbon source. Bioresource Technol., 101: 4042-4047. DOI: 10.1016/j.biortech.2010.01.052 